\title{
Effects of Degumming Waste Cooking Oil on the Physicochemical and Fuel Properties of Biodiesel
}

\author{
" MUSTAPHA, AO; AMODU, TA; ADEPOJU RA \\ Department of Chemical, Geological \& Physical Sciences, Kwara State University Malete, PMB 1530, Ilorin, Kwara State, Nigeria. \\ *Corresponding Author Email: aliru.mustapha@kwasu.edu.ng
}

\begin{abstract}
The waste cooking oil (WCO) has been a prospective and cheap feedstock for biodiesel with no competing food uses, but impurities affects biodiesel yield and result in higher production cost. This study examined the effects of degumming WCO on the physicochemical and fuel properties of biodiesel using degummed-bleached cooking oil (DCO), and methanol in the presence of sodium hydroxide catalyst. The properties and fatty acids profile were determined using the Association of Officials of Analytical Chemists (AOAC), American Society for Test and Material (ASTM) Quality, gas chromatography mass spectroscopy (GCMS) technique while the Fourier transform infrared (FTIR) gave the foremost peak regions between $1600-3600 \mathrm{~cm}^{-1}$. The $\mathrm{pH}$ of degummed cooking methyl ester (DCME), degummed-bleached cooking oil (DCO) and WCO varied between 5.83 and 8.61. Density of DCME, DCO and WCO varied between 0.88 and $0.93\left(\mathrm{~g} / \mathrm{cm}^{3}\right)$. Comparing the quality improvements between DCO and WCO, the results showed percentage increases in properties such as recovery yield $(8.5 \%)$, acid value $(61.5 \%)$, saponification value $(10.8 \%)$, iodine value $(4.9 \%)$, peroxide value $(26.9 \%)$, calorific value $(10.9 \%)$, specific gravity $(6.3 \%)$, density $(2.2 \%)$, kinematic viscosity @ $40^{\circ} \mathrm{C}(54.2 \%)$, smoke point, ${ }^{\circ} \mathrm{C}(30.9 \%)$, flash point, ${ }^{\circ} \mathrm{C}(12.1 \%)$, fire point, ${ }^{\circ} \mathrm{C}(10.8 \%)$, pour point $@ 40^{\circ} \mathrm{C}(2.3 \%)$, higher heating value $(0.7 \%)$, and cetane number $(-29.6 \%)$. The fatty acids profile in DCO has octanoic acid (5.86\%), benzoic acid (3.74\%), and hexadecanoic acid (74\%) was the most abundant. The biodiesel from DCO as feedstock have quality improvements over WCO, and values compared well with ASTM standard recommendations.
\end{abstract}

DOI: $\underline{\text { https://dx.doi.org/10.4314/jasem.v24i5.3 }}$

Copyright: Copyright (C) 2020 Mustapha et al. This is an open access article distributed under the Creative Commons Attribution License (CCL), which permits unrestricted use, distribution, and reproduction in any medium, provided the original work is properly cited.

Dates: Received: 07 March 2020; Revised: 12 April 2020; Accepted: 17 April 2020

Keywords: biodiesel, waste cooking oil, degumming, physicochemical

The world energy sector depends on the fossil fuel, coal and natural gas reservoirs to meet its energy needs (Meher et al., 2006). African country is historically associate energy lacking country that exports higher than $70 \%$ of its crude oil production. The country depends upon import of fossil fuel merchandise to sustain its growth. Diesel fuel plays a vital role in the industrial economy of African country. However, diesel engine conjointly out sends varied forms of pollutants into the setting that cause damage to human health and destroy the ecological setting (Olaoluwa et al., 2017). It's thus vital that the world increase its interest towards new sources of energy. Biodiesel fuel factory-made from vegetable oils (both edible and non-edible) or animal fats is one of the promising attainable sources that may be substituted for standard diesel fuel and produces favorable effects on the setting. Biodiesel is advised for use as a substitute for fossil fuel diesel principally as a result of it is a renewable, domestic resource with associate environmentally friendly emission profile and is without delay obtainable and perishable (Duhan et al., 2012). The biodiesel made from domestically obtainable resources supply a nice promise for future application in African country as it will facilitate in attaining abundant required energy security and being setting friendly, can facilitate to change to stricter emission norms. However, agreement to the utilization of edible oils in developing countries for biofuel functions may lead to shortages of edible oils or a rise of their costs. Therefore, it's necessary to seek out new feedstock acceptable biodiesel production, which might not drain the edible edible fat provisions. However, the utilization of waste oil (WCO), without minimum cleansing methods of degumming, bleaching and neutralization, will cause difficulties like high processing losses because of their emulsifying properties, rot and darken the oil because of their thermal instability, and high free fatty acids (FFA). To stop these difficulties, the method of degumming and bleaching permits the impurities like super molecule, phosphatides and colorants to be removed. (Idoko, et al., 2013). Therefore the objective of this work was to examine the effects of degummed waste cooking oil (DCO) on the physicochemical and fuel properties of biodiesel using methanol in the presence of sodium hydroxide catalyst.

\section{MATERIALS AND METHODS}

Materials and Chemicals: Chemicals and apparatus were obtained from Sigma Aldrich (Gillingham Dorset, UK), LGC (Teddington Middlesex, UK), and Cerrilliant (Round Rock, TX, USA). Biodiesel analyses were carried out using reflux set, micropipette, thermostated water-bath, digital hot plate/magnetic stirrer, separating funnel, pycnometer (ASTM D941), bomb calorimeter (Parr-1351 from Parr Instrument Company, Moline, IL, USA), 
Cannon-Fenske viscometer ostwald (Cannon Instrument Co., State College, PA, USA) etc, and $\mathrm{pH}$ meter (Hanna HI 4212 model).

Sample Collection: Waste vegetable oil (WCO) of sunflower (helianthus) was obtained from a food edifice in Ilorin, Kwara State, Nigeria was made from deep preparation of foods and was used as feed stock of biodiesel production.

Degumming processes: Waste cooking oil (WCO) purification was a degumming process that involved removing impurities before economical transesterification to produce DCO (Olaoluwa et al., 2017).

Bleaching treatment: The degummed oil was measured, heated to about $100{ }^{\circ} \mathrm{C}$ and activated charcoal was added and the mixture was heated up to 45 minutes with constant stirring (Olaoluwa et al., 2017).

Trans-esterification process: The acid esterification needed the free carboxylic acid (FFA) worth to be brought below $2 \%$, for the transesterification to proceed (Rahadianti et al., 2018 Trans-esterification method of DCO to DCME was the mixture of DCO and methanol to be heated and stirred for 1 hour at $65^{\circ} \mathrm{C}$, at oil to methanol molar relation of $1: 6$ in the presence of $\mathrm{NaOH}$ as catalyst (Akubugowo et al. 2008).

Physicochemical properties: WCO, DCO, and DCME properties were determined using the American Society for Test and Material (ASTM, 2003) quality evaluations and Association of Officials of Analytical Chemists (AOAC, 2012).

Chemical properties: Chemical properties which include acid value $(\mathrm{mgKOH} / \mathrm{g})$, iodine value $\left(\mathrm{mgI}_{2} / 100 \mathrm{~g}\right)$, peroxide value $\left(\mathrm{MeqO}_{2} / \mathrm{Kg}\right)$, and saponification value $(\mathrm{mgKOH} / \mathrm{g})$ and free fatty acids (AOAC, 2012).

Determination of fuel properties: The pour, flash, cloud, smoke points, specific gravity higher heating value, kinematic viscosity, and cetane number by ASTM D6751-09 (Leevijit et al., 2016).

Profile of Free Fatty Acids: Determination of free fatty acids profile of DCME: GC-MS analysis was conducted using Varian 3800 gas -chromatography including Agilent MS capillary column (30 m x zero. $25 \mathrm{~mm}$ i.d)

FTIR measurement: FTIR analysis was determined with Shimadzu instrument. $\mathrm{KBr}$ (Potassium bromide, qualitative analysis grade) was grounded into (powdery form) pelletized (with hydraulic press) and scanned at a frequency vary of $4000-400 \mathrm{~cm}^{-1}$

\section{RESULTS AND DISCUSSION}

Chemical properties of WCO, DCO, and DCME: The acid value was drastically reduced after degumming to $2.27 \mathrm{mgNaOH} / \mathrm{g}$. The acid values of $5.89 \mathrm{mg} / \mathrm{g}$ found in WCO before refinement was terribly high, which can result to larger variety of free fatty acids out there within the oil because of continuous hydrolytic cleavage of organic compound bonds throughout preparation processes. The large reduction of $61.5 \%$ FFA within the DCO the usage prospect of the used oils, and it's gained higher domestic and industrial use with improved resistance to oxidative harm. The acid values were: WCO (5.89 $\mathrm{mg} / \mathrm{KOH}), \operatorname{DCO}(2.27$ $\mathrm{mg} / \mathrm{KOH})$ and DCME $(0.05 \mathrm{mg} / \mathrm{KOH})$, respectively.

Results obtained were presented in Table 1 for the chemical parameters for WCO, DCO, and DCME. However, the definite quantity during this work was significantly not up to the $6.1721 \mathrm{mg} / \mathrm{KOH}$ from the biodiesel made from waste vegetable oil reported by Rahadanti, et al., (2018). The acid values ranges of $1.32-3.6 \mathrm{mg} / \mathrm{KOH}$ have additionally been reported for waste vegetable oil within the literature by Muhammad and Bhargavi (2015). Again, Omojola, et al., (2019) reported the acid values of some waste cooking oils like sunflower, oleomargarine, sunf oil and oil have 2.29, 2.87, 0.72 and $0.66(\mathrm{mg} / \mathrm{KOH})$ against the definite quantity of $5.89 \pm 0.14(\mathrm{mg} / \mathrm{KOH})$ discovered during this work. However, definite quantity of $0.03 \mathrm{mg} / \mathrm{KOH}$ reported for RCME here falls at intervals of the ASTM D6751-09 Standards (< $0.8 \mathrm{mg} / \mathrm{KOH}$ ) (ASTM, 2003). The peroxide value of WCO after degumming ranged from 2.60 to $1.90 \mathrm{Meq}$ $\mathrm{O}_{2} / \mathrm{kg}$, representing about $26.9 \%$ reduction. The variations in peroxide values of 65.76 and 59.64 relative atomic mass $\mathrm{Meq}_{2} / \mathrm{kg}$ were discovered from refinement of citrullus. colocynthis and pongamia pinnata oils were earlier reported (Duhan, et al., 2012). However, this peroxide value falls at intervals of the desired value for peroxide price by Codex $(10 \mathrm{meq}$ $\mathrm{O}_{2} / \mathrm{kg}$ ) for edible fat deterioration. Also, $2.96 \pm 0.34$ (Meq $\mathrm{O}_{2} / \mathrm{kg}$ ) reported for RCME falls at intervals of the ASTM D6751-09 Standards (10 Meq $\mathrm{O}_{2} / \mathrm{kg}$ ). The iodine values obtained for WCO $\left(146.64 \mathrm{I}_{2} / 100 \mathrm{~g}\right)$, $\operatorname{DCO}\left(139.51 \mathrm{I}_{2} / 100 \mathrm{~g}\right)$ and RCME (119.09 $\left.\mathrm{I}_{2} / 100 \mathrm{~g}\right)$ shows outstanding improvement, respectively.

The slight reduction of $4.9 \%$ in iodine value of $\mathrm{WCO}$ was discovered after degumming. This result shows the degummed oil possessed higher oxidative stability which will use for industrial applications. Duhan, et al., (2012) reported a reduction rate of $25.59 \%$ and $27.37 \%$ of iodine values of two samples of waste cooking oils after refinement. Omojola et al., (2019) reported the iodine values of some waste cooking oils like sunflower, depot oleomargarine, sunf oil and oil as $111.1,54.9,116.7$ and $81.7(\mathrm{mg} / \mathrm{KOH})$ against the iodine value of $5 . .89 \pm 0.14(\mathrm{mg} / \mathrm{KOH})$ discovered in this work. 
Table 1: Chemical and fuel properties of waste, degummed cooking oil and biodiesel

\begin{tabular}{|c|c|c|c|c|c|}
\hline Properties & $\begin{array}{l}\text { Waste } \\
\text { cooking oil } \\
\text { (WCO) }\end{array}$ & $\begin{array}{l}\text { Degummed } \\
\text { coolaing } \\
\text { (DCO) }\end{array}$ & $\begin{array}{l}\text { Comparable } \\
\text { differences } \\
\text { in properties } \\
(\%)\end{array}$ & $\begin{array}{l}\text { Degummed } \\
\text { cooking oil } \\
\text { based methyl } \\
\text { ester (DCME) }\end{array}$ & $\begin{array}{l}\text { ASTM } \\
\text { D6751-09 \& } \\
\text { EN14214 } \\
\text { Standards } \\
\end{array}$ \\
\hline Acid value, $(\mathrm{mg} / \mathrm{KOH})$ & $5.89 \pm 0.14$ & $2.27 \pm 0.01$ & 61.5 & $0.05 \pm 0.01$ & $<0.8$ \\
\hline Saponification, (mg/KOH) & $197.5 \pm 2.1$ & $176.11 \pm 0.01$ & 10.8 & $194.45 \pm 0.02$ & $<312$ \\
\hline Iodine Value, $\left(\mathrm{I}_{/} / 100 \mathrm{~g}\right)$ & $146.6 \pm 0.2$ & $139.51 \pm 0.2$ & 4.9 & $119.09 \pm 0.67$ & $<120$ \\
\hline $\begin{array}{l}\text { Peroxide Value, }\left(\mathrm{Meq}_{\mathrm{O}} \mathrm{O}_{2} \mathrm{~kg}\right) \\
\text { Ester value, }(\mathrm{mg} / \mathrm{KOH}) \\
\text { Calorific value }(\mathrm{J} / \mathrm{Kg}) \\
\text { Glycerine }(\%)\end{array}$ & $\begin{array}{l}2.60 \pm 0.00 \\
191.61 \pm 2.0 \\
-8180.65 \\
10.47\end{array}$ & $\begin{array}{l}1.90 \pm 0.01 \\
173.84 \pm 0.02 \\
-7283.26 \\
9.50\end{array}$ & $\begin{array}{l}26.9 \\
9.3 \\
10.9 \\
9.3\end{array}$ & $\begin{array}{l}4.16 \pm 0.34 \\
301.40 \pm 0.03 \\
-7900.37 \\
16.46\end{array}$ & 10 \\
\hline FFA $(\%)$ & 2.96 & $\begin{array}{l}1.14 \\
\text { Fuel properties }\end{array}$ & 61.5 & 0.03 & 0.5 \\
\hline Yield (\%) & 100 & 91.5 & 8.5 & 98.5 & - \\
\hline $\mathrm{pH}$ & 8.65 & 7.92 & 8.0 & 5.83 & - \\
\hline Specific gravity & 0.95 & 0.89 & 6.3 & 0.87 & $0.86-0.92$ \\
\hline Density at $40^{\circ} \mathrm{C},\left(\mathrm{g}^{\circ} \mathrm{cm}^{3}\right)$ & 0.93 & 0.91 & 2.2 & 0.89 & 0.88 \\
\hline Kinematic viscosity at $40^{\circ} \mathrm{C}\left(\mathrm{mm}^{2} / \mathrm{s}\right)$ & 38.40 & 17.6 & 54.2 & 4.30 & $1.90-6.0$ \\
\hline Cetane number (min) & 35.5 & 45.9 & -29.6 & 47.6 & $\geq 47$ \\
\hline Smoke point, $0^{\circ} \mathrm{C}$ & 194 & 134 & 30.9 & 133 & 130 \\
\hline Flash point, ${ }^{\circ} \mathrm{C}$ & 149 & 131 & 12.1 & 149 & 150 \\
\hline Fire point, $\mathrm{S}$ & 185 & 165 & 10.8 & 171 & 170 \\
\hline Pour point, "Se & -3 & -4 & 2.3 & -13 & -20 \\
\hline Higher heating value $(\mathrm{MJ} / \mathrm{kg})$ & 44.50 & 44.20 & 0.7 & 41.01 & EN14214 \\
\hline
\end{tabular}

The iodine price of $117.99 \pm 0.67 \mathrm{I} 2 / 100 \mathrm{~g}$ discovered in this work were comparable to the iodine values determined elsewhere and additionally falls at intervals of the ASTM D6751-09 standards (ASTM, 2003).

The results for saponification value show that each WCO and DCO includes fatty acids of moderate long chain lengths (C16-C20) because of their comparatively low saponification values, i.e. both oils have values below ASTM normal value of $\geq 312$. Duhan, et al., (2012) additionally reported increase in saponification value of 13.43 and $13.46 \mathrm{mg} / \mathrm{KOH}$ for citrullus. colocynthis and pongamia pinnata oils after refinement. The saponification value ranges of 188.2 $207 \mathrm{mg} / \mathrm{KOH}$ were reported by Muhammad and Bhargavi (2015) indicating the suitableness of oil capable of additional applications.

Fuel properties of WCO, RCO, and DCME: The recovery percentage: The yield of DCO from $\mathrm{WCO}$ was $91.5 \%$, whereas the yield of DCME was $98.5 \%$. Biodiesel yields from waste cooking oil by two methods of microwave heating and convectional heating in the literature had created $92 \%$ yield without oil refinement. Degumming of the WCO to DCO so increased the yield of oil.

Specific gravity: In Table 1, the specific gravity values for WCO and DCO were between $0.95-0.89$ and biodiesel was 0.87 as bestowed. The specific gravity are vital factors in the international edible oil trade market with an appropriate limit of $0.86-0.92$ at room temperature (ASTM D6751-09). Decrease in the specific density of 0.89 was as results of the removal of unwanted substances like free fatty acids, and different chemical reaction product present in the oil. Similar reduction in specific density (0.87) was obtained for the refinement of waste cooking oils of Baphia nitida and Gliricidia sepium (Adewuyi, et al., 2009).

Density and kinematic viscosity: Fuel density affects fuel performance. Other fuel properties, such as heating value and viscosity are powerfully connected to density. Fuel density is one in all the factors that have an effect on the atomization and combustion. The densities for WCO, RCO and RCME obtained were 0.93, 0.91, and $0.89\left(\mathrm{~g} / \mathrm{cm}^{3}\right)$, respectively. Mohammed and Bhargavi (2015) earlier reported the density ranges of $0.91-0.92\left(\mathrm{~g} / \mathrm{cm}^{3}\right)$ and Rahadanti, et al., (2018) equally reported $0.91(\mathrm{~g} / \mathrm{cm} 3)$ for waste cooking oils. Omojola, et al., (2019) reported the densities of some waste cooking oils like sunflower, oleomargarine, sunfoil and palm oil as $0.920,0.917$, 0.920 and $0.904\left(\mathrm{~g} / \mathrm{cm}^{3}\right)$ against the observed density of $0.93 \mathrm{~g} / \mathrm{cm}^{3}$ reported for waste sunflower oil in this study. This suggest that biodiesel from degummed oil with the alkali $(\mathrm{NaOH})$ as catalyst would have higher fuel performance due to its lower density of 0.88 (ASTM, 2003).

The viscosity of oil after degumming the RCO is in Table 1. Viscosity is commonly perceived as thickness, or resistance to running. The viscosity of vegetable oils is influenced principally by fatty acid composition and amount of contaminants. Kinematic viscosities of WCO, RCO and RCME were found to be $38.40,17.60,9.00$ and $4.30 \mathrm{~mm}^{2}$ at $40^{\circ} \mathrm{C}$ respectively. Prafulla, et al., (2012) reported viscosity of $28.8 \mathrm{~mm}^{2}$ at $40^{\circ} \mathrm{C}$ for waste cooking oil and $6.25-$ $3.10 \mathrm{~mm}^{2}$ at $40^{\circ} \mathrm{C}$ for waste cooking methyl ester. The value of $8.88 \mathrm{~mm}^{2}$ at $40^{\circ} \mathrm{C}$ was given by Rahadanti, et al., (2018) for viscosity characteristic determination. Kinematic viscosity had been reported by Maurizio, et al., (2014) in the ranges of $36.4-42 \mathrm{~mm}^{2}$ at $40^{\circ} \mathrm{C}$. In 
keeping with ASTM (2003) specifications for biodiesel, kinematic viscosity property should be within the range of $1.9-6.0 \mathrm{~mm}^{2} / \mathrm{s}$. The kinematic viscosity value of $2.30 \mathrm{~mm}^{2}$ at $40^{\circ} \mathrm{C}$ conformed to international standards for biodiesel. Also, Omojola, et al., (2018) reported the viscosities at $40^{\circ} \mathrm{C}$ of some waste cooking oils like sunflower, margarine, sunfoil and palm oil as $31.38,40.93,43.52$ and $44.25\left(\mathrm{~mm}^{2} / \mathrm{s}\right)$ against the determined kinematic viscosity of 38.40 $\mathrm{mm}^{2} / \mathrm{s}$ reported in this work.

Centane number: Cetane number of fuel indicates the degree of its ignition feature for compression ignition engines. The high cetane number of each DCO and DCME were 45.97 and 47.64 (min), it showed the biodiesel was smart for fuel application, since ASTM of $47 \mathrm{~min}$ was the quality (ASTM, 2003). High cetane number guarantees good cold start and smooth running of the engine. Cetane number indicates the degree of its ignition feature for compression ignition engines (Codex, 1992).

Smoke, flash, fire and pour points: The smoke, flash and fire points are temperatures that oil is heated and also the mixture of vapour and air above the oil will go up in flames. These parameters offer information on the storage capability of the oil and usage safety. The smoke point values obtained from the $\mathrm{WCO}$ and $\mathrm{DCO}$ were $194^{\circ} \mathrm{C}$ and $134^{\circ} \mathrm{C}$ respectively. The smoke point of DCO decreased; however, it was higher than $130^{\circ} \mathrm{C}$. This implied the oil might not be good for frying but safe as fuel because it will not ignite at cold temperature. The DCME (biodiesel) had slightly higher smoke point $\left(133^{\circ} \mathrm{C}\right)$, flash point $\left(149^{\circ} \mathrm{C}\right)$, fire point $\left(171^{\circ} \mathrm{C}\right)$ and pour point $\left(-3^{\circ} \mathrm{C}\right)$, whereas the $\mathrm{DCO}$ had smoke point $\left(134^{\circ} \mathrm{C}\right)$, flash point $\left(131^{\circ} \mathrm{C}\right)$, fire

point $\left(165^{\circ} \mathrm{C}\right)$, and pour purpose $\left(-4^{\circ} \mathrm{C}\right)$, respectively. According to Omojola, et al., (2019), they reported the pour points (congealing temperature) of some waste cooking oils like sunflower, oleomargarine, sunfoil and palmoil as $-8.65,0.3,-.9 .8$ and $10.25\left({ }^{\circ} \mathrm{C}\right)$ against the determined pour point of $-3^{\circ} \mathrm{C}$ reported for waste sun flower oil in the present study. The value conforms to the specification suggested by ASTM, (2003).

The higher heating value: The heating value for biodiesel in European standard set minimum value of $35 \mathrm{MJ} / \mathrm{kg}$ (EN14214). This obtained biodiesel combustion values was $41.01 \mathrm{MJ} / \mathrm{kg}$ that was beyond the specification recommended. Based on the high heat of combustion value, the biodiesel can serve as attainable substitute to fuel. The caloric value of biofuels is a very important parameter for the comparison of fuel properties with crude oil diesel.

Impact of changes within the fatty acid profile on biodiesel fuel properties: The fatty acid profiles of the DCO and WCO in relative to their retention time and proportion composition were obtained. The fatty acids profile additionally showed comparable proportion in reduction with reference to octanoic acid (20\%), saturated fatty acid $(72.4 \%)$ but increase in 9Octadecanoic acid $(84.60 \%)$, respectively and results obtained were presented in Table 2 . The hexadecanoic acid $(74.0 \%)$ was the foremost fatty acid followed by octanoic acid (5.86\%), and benzoic acid (3.74). The 9octadecenoic acid; octadecanoic acid; 9, 12, 15 octadecatrienoic acid and heptadecanoic acid were found in WCO, but weren't found in the DCO. Also, a persistent increase in value of peroxide is due to multiple high temperatures that energized water to act as a weak nucleophile for organic compound linkages. Table 2: Comparison of fatty acid profiles of waste and degummed cooking oils

\begin{tabular}{|c|c|c|c|c|}
\hline \multicolumn{5}{|c|}{ Waste cooking oil (WCO) } \\
\hline $\begin{array}{l}\text { Retention } \\
\text { Time }\end{array}$ & Composition & Saturation & $\begin{array}{l}\text { Composition } \\
\text { (\%) }\end{array}$ & $\begin{array}{l}\text { Comparable } \\
\text { Difference }(\%)\end{array}$ \\
\hline 21.37 & Qctanoic acid & $(\mathrm{Cl0}=2)$ & 4.86 & - \\
\hline 23.01 & Benzoic acid & $(\mathrm{Cl1}: 2)$ & 3.74 & - \\
\hline 32.85 & Hexadecanoic acid & (C18:2) & 1.01 & - \\
\hline 33.41 & 9-Octadecenoic acid & $(\mathrm{Cl9}-2)$ & 6.42 & - \\
\hline 36.92 & Qctadecamoic acid & $(\mathrm{C} 20: 2)$ & 0.03 & - \\
\hline 39.52 & $\begin{array}{l}9,12,15 \\
\text { Qstadecatrienois acid }\end{array}$ & $(\mathrm{Cl9}-2)$ & 1.02 & - \\
\hline 39.98 & Detadecanois acid & $(\mathrm{C} 20: 2)$ & 29.85 & - \\
\hline 40.69 & Heptadecanoic acid & $(\mathrm{Cl9}-2)$ & 10.02 & - \\
\hline 41.08 & Rentadecanois acid & $(\mathrm{Cl} 17: 2)$ & 38.51 & - \\
\hline 42.84 & 9-Octadecenoic acid & (C21:4) & 6.42 & - \\
\hline \multicolumn{5}{|c|}{ Degummed cooking oil (RCO) } \\
\hline 14.50 & Qctanoic acid & $(\mathrm{Cl0}=2)$ & 5.86 & 20.6 \\
\hline 15.87 & Benzoic acid & $(\mathrm{Cl1}: 2)$ & 3.74 & 0.00 \\
\hline 22.0 & Hexadecanoic acid & $(\mathrm{Cl} 18-2)$ & 74.16 & 72.4 \\
\hline 42.84 & 9-Octadecenoic acid & (C21:4) & 0.99 & 84.6 \\
\hline
\end{tabular}

The FTIR analysis of biodiesels from $W C O$ and RO: The Fourier Transform Infra-red (FTIR) spectrum analysis results for biodiesel showed the foremost IR peak regions that indicated chemical changes from $1600-3600 \mathrm{~cm}^{-1}$. The spectral bands $1377.22 \mathrm{~cm}-1$ showed the presence of glycerin cluster $\mathrm{O}-\mathrm{CH}_{2}$ (mono, di and triglycerides). The IR spectral $1747.57 \mathrm{~cm}-1$ corresponds to the presence of organic compound group within the degummed oil and biodiesel. IR band $1464.02 \mathrm{~cm}^{-1}$ was also considered as a result of its uneven bending and likewise match with $-\mathrm{CH}_{3}$.

Conclusion: Degumming treatment have shown the foremost effective way for the reduction of the 
oxidation products present in the WCO with improved properties for emulsification and biodiesel production. The utilization of WCO reduces the high production cost of biodiesel; solves problems associated with the disposal of WCO; eliminates contamination of aquatic and terrestrial habitats, and generates profits for smallscale businesses.

\section{REFERENCES}

Adewuyi, A; Oderinde, RA; Ajayi, IA (2009). The Metal Composition, Proximate Properties and the Effect of Refining on the Physico-Chemical Characterization of Baphia nitida and Gliricidia sepium Seed and Seed Oil. J Food Technol. 7(2): 43-49

Akubugwo, IE, Chinyere, V; Ugbogu, AE (2008). Comparative Studies on Oil from Some Common Plant Seeds in Nigeria. Pakistan J. of Nutr. 7(4): 570-573.

American Society for Testing Materials (ASTM). ASTM Standards Methods: ASTM pub; Philadelphia. (2003)

CODEX Alimentarius Commisions. (1992). Recommended International Statndards for Edible Arachis Oil'. Food and Agricultural Organization of the United Nation. World Health Organizaton, Geneva, Switzerland. (1): 6-19

Duhan, A; Duhan, S; Kumari, B (2012). Effect of Chemical Refining on Citrullus Colocynthis and Pongamia Pinnata Seed Oil. Afri. J. of Food, Agric. Nutria. Develop. 12, (3): 55-68

Idoko, O; Bwai, MD; Emmanuel, SA; Thomas, SA (2013). Effect of bleaching and degumming on the physicochemical Properties and antioxidant activity of palm oil. Res. J. in Eng. and Appl. Sci. 2, (5): 343-345.
Leevijit, T; Prateepchaikul, G; Maliwan, K; Mompiboon, P; Okaew, S; Eiadtrong, S (2016): Fuel (182): 509-516.

Maurizio, C; Sonia, C; Silvia, C (2014). Energy Procedia. (45): 198 - 206.

Meher, LC; Sagar, DV; Naik, SN. (2006). Technical aspects of biodiesel production by Transesterification - a review. Renew. Sustain. Energy Rev. (10): 248-268.

Mohammed, A; Bhargavi, R (2015). Biodiesel production from waste cooking oil. J. Chem. and Pharm. Res. 7(12): 670-681

Olaoluwa, RO; Abolanle, SA; John, AOO; Efere, MO; Olatunji, SO; Adedayo, MS; Muib, A A; Oyedare, MA (2017). Refining, Toxicology Study and Biodiesel Potentials of Used Vegetable Oils. Am. J. of Food Sci. and Technol. 3, (5):78-88

Omojola, A; Emmanuel, IO; Freddie, L; Inambao (2019). Comparative study of properties and fatty acid composition of some neat vegetable oils and waste cooking oils. Int. J. of Low-Carbon Technol. (14): 417-425

Prafulla, DP; eera, G; Harvind, KR; Tapaswy, M; Shuguang, D (2012). Biodiesel Production from Waste Cooking Oil Using Sulfuric Acid and Microwave Irradiation Processes. J. of Environ Protection. (3), 107-113.

Rahadianti, ES; Yerizam and Martha (2018). Biodiesel Production from Waste Cooking Oil Indones. $J$. Fund. Appl. Chem. 3(3):77-82 